\title{
PENGARUH PEMBERIAN TERAPI TERTAWA TERHADAP TINGKAT STRES PADA IBU YANG MEMILIKI ANAK AUTIS DI KOTA PEKANBARU
}

\author{
Saniya \\ Keperawatan Universitas Abdurrab Jl. Riau Ujung No. 73 Tampan \\ Email : saniya@univrab.ac.id
}

\begin{abstract}
Laughter therapy is one therapy that can be used to reduce stress levels. This study aims to determine the effect of laughter therapy on stress levels in mothers who have autistic children in SLB Pembina Pekanbaru. The design used in this study was a Quasy Experiment with a One Group Pre Test Posttest design, with a total sample of 15 respondents. This research instrument consisted of a questionnaire that contained questionnaires about stress levels using the DASS scale, which is a subjective scale formed to measure the negative emotional status of stress levels. The analysis used is Univariate and Bivariate analysis. T-dependent test is used to see the level of stress on the mother / respondent before and after laughter therapy is given. The results showed that the average before getting a laugh therapy was 71.27 with a standard deviation of 5.788 and after getting a laugh therapy was 32.80. For the value of $p=$ 0,000 smaller than 0.05. From these values it was concluded that the research hypothesis was accepted meaning that there was an effect of giving laughter therapy to stress levels in mothers of children with autistic children, SLB Pembina Pekanbaru. The implications of laughter therapy in this study are as one alternative therapy to reduce stress levels in mothers who have autistic children.
\end{abstract}

Keywords: Stress, Laughter Therapy, Autism

\begin{abstract}
ABSTRAK
Terapi tertawa merupakan salah satu terapi yang dapat digunakan untuk menurunkan tingkat stres. Penelitian ini bertujuan untuk mengetahui pengaruh pemberian terapi tertawa terhadap tingkat stress pada ibu yang memiliki anak autis di SLB Pembina Pekanbaru. Desain yang digunakan dalam penelitian ini adalah Quasy Experiment dengan rancangan One Group Pre Test Posttest, dengan jumlah sampel sebanyak 15 responden. Instrumen penelitian ini terdiri dari kuisoner yang berisi kusioner tentang tingkat stress dengan menggunakan skala DASS, yaitu separangkat skala subjektif yang dibentuk untuk mengukur status emosional negative dari tingkat stress. Analisis yang digunakan adalah analisis Univariat dan Bivariat. Uji t-dependen digunakan untuk melihat tingkat stress terhadap ibu/responden sebelum dan sesudah diberikan terapi tertawa. Hasil penelitian menunjukkan bahwa rata-rata sebelum mendapatkan terapi tertawa adalah 71,27 dengan standar deviasi 5,788 dan sesudah mendapatkan terapi tertawa adalah 32,80. Untuk nilai p=0,000 lebih kecil dari 0,05. Dari nilai tersebut disimpulkan bahwa hipotesis penelitian diterima berarti terdapat pengaruh pemberian terapi tertawa terhadap tingkat stress pada ibu yang memiliki anak autis SLB Pembina Pekanbaru. Implikasi terapi tertawa pada penelitian ini adalah sebagai salah satu terapi alternatif untuk menurunkan tingkat stres pada ibu yang memiliki anak autis.
\end{abstract}

Kata Kunci : Stres, Terapi Tertawa, Autis 


\section{PENDAHULUAN}

Anak ialah anugerah yang terindah bagi setiap orang tua karena anak merupakan tumpuan harapan dan kebanggaan dari orangtuanya. Setiap orangtua tentunya mengharapkan anak memiliki proses tumbuh kembang yang optimal, namun sering terjadi harapan yang tidak sesuai dengan kenyataan, yang mana anak menunjukkan masalah perkembangan sejak usia dini. Salah satu contoh masalah perkembangan yang dialami anak ialah autisme (Rike, 2011).

Autisme dapat menyerang siapa saja, tanpa melihat ras, tingkat pendidikan dan status ekonomi sosial. Ketidakterbatasan ini menjadikan autisme dapat menyebar dengan cepat dan menjadi lebih umum dibandingkan gangguan lainnya (Marpaung dalam Hariansib, 2014). Data dalam Sastry (2014) juga mengungkapkan bahwa Centers for Disease Control and Prevention (CDC) menemukan bahwa 1 persen dari anak berusia 8 tahun di Amerika Serikat memenuhi kriteria Autisme di tahun 2006. Hal ini berarti, hanya untuk anak berusia 8 tahun sudah terdapat 40.000 individu yang mengalami Autisme. Antara tahun 1990 hingga 2002, kelompok anak yang didiagnosa mengidap autis meningkat hingga 600 persen (Sastry, 2014).

Prevalensi autis beberapa tahun terakhir ini mengalami kenaikan yang signifikan. Center for Diseases Control and Prevention (CDC) di Amerika Serikat pada bulan Maret 2013 melaporkan, bahwa prevalensi autis meningkat menjadi 1:50 dalam kurun waktu setahun terakhir. Hal tersebut bukan hanya terjadi di negaranegara maju seperti Inggris, Australia, Jerman dan Amerika namun juga terjadi di negara berkembang seperti Indonesia. Prevalensi autis di dunia saat ini mencapai 15-20 kasus per 10.000 anak atau berkisar $0,15-0,20 \%$. Jika angka kelahiran di Indonesia 6 juta per tahun maka jumlah penyandang autis di Indonesia bertambah $0,15 \%$ atau 6.900 anak per tahunnya.

Berdasarkan data yang di dapatkan dari Dinas Pendidikan di Provinsi Riau Kota Pekanbaru (2015) jumlah anak autis di Pekanbaru mencapai 1089 orang yang tersebar di beberapa Kabupaten. Jumlah sekolah SLB (Sekolah Luar Biasa) di wilayah Provinsi Riau ada sebanyak 39 SLB yang tersebar di beberapa daerah, seperti wilayah Pekanbaru, Dumai, Pelalawan, Bengkalis, Kep Meranti, Inhu, Kuansing, Kampar, Rohil, Rohul, Siak, dan Inhil. Di Kota Pekanbaru sendiri terdapat 12 Sekolah SLB dengan jumlah 236 murid penyandang autis, terdapat satu sekolah dengan jumlah tertinggi yaitu 35 orang murid anak autis yang sedang sekolah di SLB Pembina di wilayah Pekanbaru. (Dinas Pendidikan Provinsi Riau, 2015).

Tidak mudah bagi orang tua untuk menghadapi kenyataan bahwa anak yang dilahirkannya mengalami gangguan autis. Awalnya orang tua akan bingung karena orang tua belum memiliki pemahaman tentang autis, ada juga orang tua yang merasa shock, stress dan merasa tertuduh karena memiliki pemahaman yang salah tentang gangguan autis. Orang tua merasa bahwa anak autis terlahir akibat dosa-dosa orang tua, bahkan ada juga pasangan suami istri bertengkar lalu saling menyalahkan. Keberadaan anak autis membawa stres tersendiri bagi kehidupan keluarga, termasuk didalamnya trauma psikologis (Muhammad , 2011).

Hasil penelitian dari Olsson \& Hwang (2012) (dalam Pisula \& Kossakawska, 2010) menyimpulkan bahwa ibu yang memiliki anak autis lebih banyak mengalami stres daripada ibu yang memiliki anak normal. Twoy, Connoly \& Novak (2007) menyebutkan bahwa pemikiran dapat memahami dampak dari stres sebagai kenyataan hidup dan mampu untuk menentukan dampak yang lebih positif 
sehingga bisa menemukan solusi untuk masalah-masalah yang dihadapi (Sun, 2010).

Hasil penelitian yang dilakukan oleh Suraiya (2012) menyebutkan, orang tua yang memiliki anak autisme dapat menyebabkan stress pada orang tua. Beberapa hal yang menyebabkan stress pada orang tua yang memiliki anak autisme meliputi kebigungan diagnose, karakteristik pada anak autisme, serangkaian tes dan tempat terapi yang belum terbukti, dan sikap orang lain dari anak autis mereka.

Beragam reaksi orang tua muncul terkait dengan diagnosa autisme yang melekat pada anaknya. Beberapa reaksi emosi yang muncul dari orangtua ialah merasa terkejut, rasa tidak percaya, stress, emosi, sedih, kecemasan yang tinggi, malu, bahkan perasaan bersalah. Kebanyakan orang tua merasa sangat terpukul dan terpaksa menerima kenyataan bahwa anaknya penyandang astisme ( Safari \& Ryni dalam Davis dkk, 2015).

Stress dapat diatasi dengan berbagai terapi, salah satunya dengan cara menggunakan terapi non-farmakologi yaitu terapi tawa. Salah satu peneliti mengenai pengaruh terapi relaksasi otot progresif terhadap penurunan tingkat stress, depresi, dan kecemasan. terapi ini dapat dilakukan dengan cara memberikan stimulasi humoris dan sengaja berlatih tertawa. Terapi tertawa merupakan suatu pelatihan yang bisa membuat hidup lebih sehat, tenang, dan nyaman, serta menunjukkan getaran otak pada frekuensi gelombang alfa yang membuat orang merasa rileks dan santai. Penelitian ini dilakukan oleh Dr. Mahdan Kataria yang merupakan pendiri dari gerakan klub tawa dunia (Armajayanthi, 2016).

Pemberian terapi tertawa bertujuan membantu membentuk pola pikir positif sehingga seseorang akan berfikir dengan cara yang positif. Tertawa merupakan cara yang lebih positif. Tertawa merupakan cara yang paling ekonomis dalam melawan stres. Tertawa akan merileks otot-otot yang tegang. selain itu tertawa juga berperan dalam menurunkan kadar hormon stres epineprine dan kortisol (Tarigan, 2009). Konsep terapi humor dan tertawa ini berupa mendapat perhatian dunia medis setelah diterbitkan artikel "Anatomy of an lllness" dalam New England Journal of Medicine oleh Norman Cousins pada tahun 1976. Menurut Dr. Lee Berk (Terapi Tawa, 2010), seorang imunolog dari Loma Linda University di California USA, tertawa bisa mengurangi peredaran dua hormone dalam tubuh, yaitu efinefrin dan kartisol (hormon yang dikeluarkan ketika stress) yang dikeluarkan oleh hipotalamus.

Dari hasil survei pendahuluan yang peneliti lakukan di Sekolah Luar Biasa (SLB) Pekanbaru yang berlokasi di Provinsi Riau Kabupaten Kota Pekanbaru yang terletak di Jl.Segar di dapatkan bahwa jumlah orang tua yang memiliki anak autis sebanyak 30 anak autis. Hasil pemberian kuesioner peneliti kepada 10 orang tua didapatkan bahwa 7 orang mengalami stress berat, 2 orang mengalami stress sedang, dan 1 mengalami stress ringan.

Berdasarkan fenomena diatas maka peneliti tertarik untuk melihat dan meneliti lebih jauh tentang "Pengaruh Pemberian Terapi Tertawa Terhadap Tingkat Stress Pada Ibu Yang Memiliki Anak Autis Di SLB Pembina Provinsi Riau .

\section{METODOLOGI PENELITIAN}

Jenis penelitian ini adalah penelitian kuantitatif. Desain penelitian adalah quasy eksperiment dengan mengunakan "one grup pre dan post test". Responden akan diberikan terapi tertawa, diawali dengan pengukuran sebelum pemberian terapi tertawa (pretest), dan setelah pemberian terapi tertawa diadakan kembali (posttest) (Nursalam, 2008). Kegiatan penelitian ini dilakukan Di Sekolah Luar Biasa (SLB) 
Pembina Pekanbaru pada bulan FebruariMei Tahun 2018.

Pada penelitian ini yang menjadi populasi dan subjek penelitian adalah ibu yang berada Di Sekolah Luar Biasa (SLB) Pembina Pekanbaru sebanyak 30 orang. Penelitian ini menggunakan teknik nonprobability sampling dengan jenis purposive sampling. Jumlah sampel yang akan digunakan sebanyak 15 orang (Burn \& Grove, 2005).

Pengumpulan data penelitian ini dilakukan dengan cara mengisi kuisioner. Kuesioner yang digunakan untuk menentukan tingkat stress yaitu Depression Anxiate Stres Scale 21 (DASS 21). Pengukuran dengan lembar kuesioner di lakukan sebelum (pretest) dan setelah (posttest) dilakukan terapi tertawa. Setelah mengukur tingkat stress, lalu peneliti memberikan terapi tertawa sebanyak 3x seminggu dalam waktu 15-20 menit. Analisis data di lakukan secara univariat dan bivariat menggunakan uji simple $T$ test (dependent Simpel T Test).

\section{HASIL PENELITIAN}

Berdasarkan penelitian tentang Pengaruh Pemberian Terapi Tertawa Terhadap Tingkat Stress Pada Ibu Yang Memiliki Anak Autis Di SLB Pembina Pekanbaru.

1. Analisa Univariat

a. Karakteristik responden

1) Umur

Tabel 1

Distribusi frekuensi responden berdasarkan umur ibu di SLB Pembina Pekanbaru

\begin{tabular}{cccc}
\hline No & Umur & Frekuensi & $\begin{array}{c}\text { Persentase } \\
(\%)\end{array}$ \\
\hline 1 & $17-25$ & 1 & 6,7 \\
\hline 2 & $26-35$ & 6 & 40,0 \\
\hline 3 & $36-45$ & 8 & 53,3 \\
\hline & Total & 15 & 100 \\
\hline
\end{tabular}

Berdasarkan tabel 1 distribusi frekuensi berdasarkan umur responden sebagian besar antara 36-45 tahun (dewasa akhir) yaitu 8 orang $(53,3 \%)$.

2) Pendidikan

Tabel 2

Distribusi frekuensi responden berdasarkan pendidikan terakhir ibu yang memiliki anak autis di SLB Pembina Pekanbaru

No Tingkat Frekuensi Presentase

\begin{tabular}{cccc} 
& Pendidikan & & $(\%)$ \\
\hline 1 & SD & 1 & 6,7 \\
\hline 2 & SMP & 6 & 40,0 \\
\hline 3 & SMA & 8 & 53,3 \\
\hline & Total & 15 & 100
\end{tabular}

Berdasarkan tabel 2 distribusi frekuensi berdasarkan pendidikan terakhir responden, dapat dilihat bahwa sebagian distribusi responden yang tamatan sekolah SMA yaitu mencapai 8 orang $(53,3 \%)$.

3) Status pernikahan

Tabel 3

Distribusi frekuensi responden berdasarkan status pernikahan ibu yang memiliki anak autis di SLB Pembina Pekanbaru

\begin{tabular}{cccc}
\hline No & $\begin{array}{c}\text { Status } \\
\text { pernikahan }\end{array}$ & Frekuensi & $\begin{array}{c}\text { Persentase } \\
(\%)\end{array}$ \\
\hline 1 & Menikah & 12 & 80 \\
\hline 2 & Cerai & 3 & 20 \\
\hline & Total & 15 & 100 \\
\hline
\end{tabular}

Berdasarkan tabel 3 distribusi frekuensi berdasarkan status pernikahan, didapatkan responden terbanyak adalah 12 orang $(80 \%)$ yaitu menikah dan 3 orang dengan status janda (20\%). 
4) Jenis pekerjaan

Tabel 4.4

Distribusi frekuensi responden berdasarkan jenis pekerjaan ibu yang memiliki anak autis di SLB Pembina Pekanbaru

\begin{tabular}{llcc}
\hline No & Pekerjaan & Frekuensi & $\begin{array}{c}\text { Persentase } \\
(\%)\end{array}$ \\
\hline 1 & IRT & 12 & 80 \\
\hline 2 & Guru & 2 & 13,3 \\
\hline 3 & Dagang & 1 & 6,7 \\
\hline & Total & 15 & 100 \\
\hline
\end{tabular}

Berdasarkan tabel 4 diketahui bahwa jenis pekerjaan responden terbanyak terdiri dari IRT (ibu rumah tangga) 12 orang (80\%), guru 2 orang $(13,3 \%)$, dagang 1 orang $(6,7 \%)$.

\section{PEMBAHASAN}

\section{Karakteristik responden}

a. Umur

Hasil penelitian yang telah dilakukan di SLB Pembina Pekanbaru didapatkan bahwa umur responden terbanyak adalah dewasa akhir yaitu 36-45 tahun mencapai 8 orang (53,3\%). Menurut Walker (2013) pada usia dewasa akhir wanita yang sudah berumah tangga sering mengalami stress yang dipicu oleh beberapa kejadian. Salah satunya terkait dengan hal-hal yang mereka harapkan. Misalnya, orangtua ingin anaknya berperestasi di sekolah, tetapi anak tidak mampu memenuhi harapan itu.

Menurut Sarifino (2011) stress pada orang dewasa disebabkan oleh factor ekonomi,pekerjaan, dan keluarga. Tetapi sumber stress yang paling menonjol adalah pekerjaan dan ekonomi. Masalah ini tampaknya menyoroti fakta bahwa keprihatinan tentang kesejahteraan financial selama pension tetapada, meskipun laporan bahwa ekonomi membaik. Banyak orang dewasa yang terus berjuang dengan aspek keuangan yang semakin menurun, dan peningkatan jumlah yang mengubah anggaran pensiun mereka untuk mengkompensasi masa ekonomi sulit.

b. Pendidikan Terakhir

Hasil penelitian yang telah dilakukan pada ibu yang stress memiliki anak autis di SLB Pembina Pekanbaru didapatkan bahwa sebagian besar distribusi responden yang tamatan sekolah SMA yaitu mencapai 8 orang $(53,3 \%)$. Perry dan Potter (2012) menyatakan latar belakang pendidikan akan membentuk cara berfikir seseorang termasuk membentuk kemampuan untuk memahami faktor-faktor yang berkaitan dengan penyakit dan menggunakan pengetahuan tersebut untuk menjaga kesehatan.

Hal ini sejalan dengan penelitian yang telah dilakukan oleh Ayu, Wayan \& Ketut (2013) dengan tingkat pendidikan responden terbanyak adalah pendidikan menengah (SMA) dengan presentase $60 \%$. Hal tersebut menunjukkan bahwa pendidikan itu dapat menuntun manusia untuk berbuat baik dan mengisi kehidupannya untuk mencapai suatu keselamatan dan kebahagiaan. Semakin tinggi tingkat pendidikan seseorang, maka semakin banyak pula pengetahuan yang dimiliki (Notoatmodjo, 2009). Hasil yang didapatkan sesuai dengan penelitian Raihan dkk (2014) karena jumlah responden yang ditemukan dilapangan paling banyak adalah berpendidikan SMA. 
c. Status Pernikahan

Penelitian yang dilakukan di SLB Pembina Pekanbaru berdasarkan karakteristik status pernikahan didapatkan responden terbanyak adalah 12 orang $(80 \%)$ yaitu menikah dan 3 orang dengan status janda (20\%). Studi yang dilakukan di Duke Uneversity menunjukan bahwa mereka yang sudah menikah (memiliki pasangan) jauh lebih sehat fisik dan mental disbanding orang-orang yang hidup sendiri tanpa pasangan. Studi ini membuktikan kalau dukungan sosial dari pasangan menikah bisa memperbaiki kesehatan dan mendapat kesejahteraan keluarga. Sementara mereka yang belum menikah atau berstatus janda dan duda lebih berisiko mengalami depresi. Hal ini sejalan dengan penelitian yang dilakukan oleh Qaimi (2013) wanita dengan single Perent adalah wanita ditinggalkan oleh suami atau bercerai atau meninggal dunia kemudian memutuskan untuk tidak menikah melainkan membesarkan anak-anaknya.wanita dengan status pernikahan single perent lebih rentan mengalami perasaan sedih, kehilangan, beban kerja, beban hidup, beban megurus anak, kurangnya dukungan keluarga sehinggan menyebabkan seseorang itu menjadi stress. Umumnya wanita single parent akan merasa tegang terhadap masa depan, dimana tidak akan lagi sesuatu seperti yang telah direncanakan sebelumnya bersama pasangan. Permasalahan yang dihadapi, seperti masalah keuangan, perumahan, kesepian dan dimana wanita tidak menemukan seseorang untuk menamggung beban bersama.

d. Jenis Pekerjaan
Berdasarkan data diketahui bahwa jenis pekerjaan responden terbanyak terdiri dari IRT (Ibu Rumah Tangga) 12 orang $(80 \%)$, Guru 2 orang (13 ,3\%), dagang 1 orang $(6,7 \%)$. Menurut WHO (2013), masalah pekerjaan diduga berkaitan dengan masalah psikologis dilingkungan pekerjaan. Kondisi kehidupan, kondisi kerja serta stres dilingkungan kerja dapat berpengaruh terhadap stress yang dialaminya. Misalnya sesorang yang tidak bekerja lebih banyak memikirkan masalah rumah tangga sedangkan yang bekerja berhubungan dengan stres lingkungan kerja dan rumah tangga sehingga berdampak terhadap stress atau depresi.

Jenis pekerjaan dapat mempengaruhi aktivitas seseorang, dimana individu yang aktivitasnya rendah beresiko mengalami stress dari pada individu yang aktif disebabkan oleh kurangnya aktivitas yang dilakukan dimana kebanyakkan hanya berdiam diri dirumah dengan rutinitas yang membuat mereka merasa suntuk. Berbeda dengan individu yang bekerja yang justru lebih banyak aktivitasnya dan menyempatkan waktu untuk melakukan olahraga. Individu yang bekerja biasanya lebih aktif dari pada individu yang tidak bekerja. Stres yang dialami oleh individu yang tidak bekerja akan meningkatkan resistensi pembuluh darah perifer dan curang jantung sehingga akan menstimulasi aktivitas saraf simpatik, adapun stres ini dapat berhubungan dengan pekerjaan, kelas sosial, dan ekonomi (Susilo \& Wulandari, 2011).

Hasil ini sesuai dengan hasil penelitian yang dilakukan Kelly Musick, guru besar analisis kebijakan menajemen Universitas Cornell, New York mengatakan bahwa betapa 
beratnya tugas seorang ibu karena hampir semua tugas rumah tangga termasuk pengasuhan dilakukannya. Mulai memasak, membersihkan rumah, hingga merawat dan mengasuh anak-anak, semua aktifitas itu memunculkan ketegangan dan stress tersendiri. Hasil ini juga diperkuat dari hasil survey Penelitian yang dilakukan oleh Elita (2013) dari lima orangtua anak peyandang autis menyatakan bahwa kelima orangtua merasa sangat kesulitan untuk merawat anak autis, terutama disaat mereka sama sekali tidak mengerti apa yang diinginkan oleh anaknya.

\section{Pengaruh pemberian terapi tertawa terhadap tingkat stres pada ibu yang memiliki anak autis}

Analisa bivariat digunakan untuk melihat perbedaan tingkat stress ibu sebelum dan sesudah pemberian terapi tertawa. Hasil penelitian ini dikatakan efektif apabila nilai $p$ value $<0.05$. Penelitian ini menggunakan uji $t$ dependen. Berdasarakan hasil pengolahan data dengan menggunakan SPSS (Statistic Program for Social Science) diperoleh hasil sebagai berikut:

Tabel 4.5

Perbedaan Mean tingkat stress sebelum (Pre-test) dan sesudah (Posttest)

\begin{tabular}{ccccc}
\hline Variabel & Mean & SD & SE & $\begin{array}{c}P \\
\text { Value }\end{array}$ \\
\cline { 1 - 4 } Pretest & 71,27 & 5,788 & 1,494 & 0.000 \\
Posttest & 32,80 & 3,028 & 0,782 & \\
\cline { 1 - 3 } Selisih & 38,47 & 2,76 & 0,712 &
\end{tabular}

Berdasarkan table 4.5 didapatkan mean tingkat stress sebelum diberikan terapi tertawa adalah 71,27 dengan standard deviasi 5,788. Dan setelah diberikan terapi tertawa didapatkan mean stress 32,80 dengan standar deviasi 3,028. Dari hasil uji $t$ dependen didapatkan adanya penurunan yang signifikan antara mean tingkat stress sebelum dan sesudah diberikan terapi tertawa, dimanan $p$ value $=0,000$ dengan $\alpha$ $5 \% \quad(\mathrm{p}<0,05)$ dengan demikian terapi tertawa efektif diberikan pada ibu dengan anak autis yang rentan stress (atau dengan stress yamg relative lebih tinggi.)

\section{SIMPULAN}

Berdasarkan Karakteristik berdasarkan umur responden didapatkan responden berumur antara 36-45 tahun (Dewasa Akhir) yaitu 8 orang (53.3\%). Karakteristik berdasarkan pendidikan responden terbanyak adalah tamatan SMA sebanyak 8 orang $(53,5 \%)$. Karakteristik berdasarkan status pernikahan menikah sebanyak 12 orang (80\%). Karakteristik responden berdasarkan pekerjaaan mayoritas adalah ibu rumah tangga( $80 \%)$.

Dari hasil uji t dependen didapatkan adanya penurunan yang signifikan antara mean tingkat stress ibu sebelum dan sesudah diberikan terapi, dimana $\mathrm{p}$ value $=0,000$ dengan $5 \%(\mathrm{p}<0,05)$ dengan demikian terapi tertawa efektif diberikan pada ibu yang memiliki tingkat stres.

\section{DAFTAR PUSTAKA}

APA, (2011). DSM III : Diagnostic and Statistical Manual of Mental Disorders

3rd ed. USA: Washington.

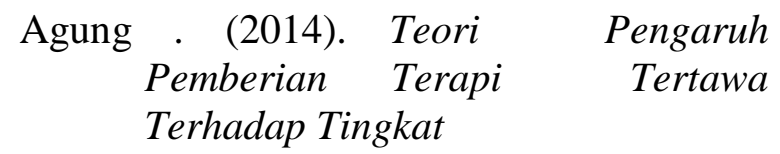


stress Pada Lanjut Usia Di PSTW Wana Saraya Denpasar. (http://journal.unair.ac.id/filerPDF/ij chnfad7c40937full.pdf).

Ardani. (2013). Psikologi Sosial untuk Perawat. Jakarta : EGC

Astuti, A. (2014). Terapi Tertawa untuk Hidup Lebih Sehat, Bahagia dan Ceria. Yogyakarta: Pustaka Larasati.

Andol (2009). Terapi Tertawa. http://m.epochtimes.co.id. Diakses : 4 November 2013.

Alhamdi, F. (2011), Autisme Suatu Gangguan Jiwa pada Anak-anak. Jakarta: Pustaka Populer Obor.

Armajayanthi, E. (2016). Studi Deskriptif Mengenai Coping Stress pada Ibu yang Memiliki Anak dengan Autism;Sebuah Penelitian di Sekolah " $X$ " Bandung (Skripsi). Fakultas Psikologi Universitas Kristen Maranatha: Bandung.

Aziz,A \& Fatma,A. (2013). Hubungan Antara Dukungan Sosial dengan Penyesuaian Diri Orang Tua yang Stress Memiliki Anak Autis. Program Studi Psikologi, Fakultas Ilmu Kesehatan Universitas Sahid Surakarta.

Christopher Sunu D. Menajemen Stres Cemas Dan Depresi. Jakarta : Balai Pustaka Falkutas Kedokteran Universitas Indonesia: 2011

Departemen Kesehatan Republik Indonesia. Pedoman Pelayanan Kesehatan Anak di Sekolah Luar Biasa (SLB).Jakarta Bakti:Husada. 2010.
Dumbre. Terapi Tertawa Untuk Hidup Lebih Sehat Bahagia \& Ceria.Yogyakarta: Pustaka Larasati ; 2012

Fina Hidayati. C, Neale, J.M,.\&Kring, A.M. (2013).Psikologi Abnormal (Edisike 4). Penerjemah (NoermalasariFajar. Trans).

Guney, Isery. (2013). The psychophysiology of Autisme. Netherlands. Chapter 1. Halaman 15.

Guntoro, Yusuf (2014). Manajemen Stres, Cemas dan Depresi. Jakarta: Fakultas. Kedokteran UI

Hafid, I. (2011). Pengasuhan Orang Tua pada Anak Retardasi Mental Ringan. Skripsi .Universitas Ahmad Dahlan. Yogyakarta.

Hayati, (2008).Riset Keperawatan Dan Teknik Penulisan Ilmiah,Jakarta: Selemba Medika.

Hastono, S. P. (2007).Besic Data Analysis For Healt Researeh Training : Analisa Data Kesehatan. Jakarta: FKMUI.

Hidayati, Fina. (2013). Pengaruh "Pelatihan Ibu Cerdas" terhadap Stres Pengasuhan pada Ibu dari Anak Autis, Jurnal Psikologi Islam (JPI),.Vol.10. No.1.Universitas Islam Negeri (UIN) Maulana Malik Ibrahim Malang.

Isnawati, L. (2015). Penyebab, Seputar Autisme dan Permasalahannya. Jakarta : Putrakembara Foundation.

Jayanthi, evanjeli.(2015). Academic stress and depression among adolescents: A cross-sectional study. Indian pediatrics, 52(3), 217-219. 
Kataria, I. 2010. Sehat Dengan Terapi Tertawa. Diakses pada tanggal 12 Oktober2015darihttp://www.mediain donesia.com/mediahidupsehat/index. php/read/2009/06/25/1325/13/Sehatdengan-Terapi-Tertawa.

Kemenkes RI. 2013. Sistem Kesehatan Nasonal. Diproleh Pada Tanggal 23 Oktober 2013. Dari WWW.PDGI.or.id.

Kementrian Pendidikan dan Kebudayaan (2012). Pedoman Pelayanan bagi Anak Autistik. DEPDIKNAS: Jakarta.

Lingga, Iffah. (2014). Hubungan Dukungan Sosial Pada Orang Tua Yang Stress Memiliki Anak Autis Di SLB Autis Harmony Solo [Skripsi]. Tidak dipublikasikan.Yogyakarta: Program Studi Ilmu.

Lyon.(2012). Konsep stres dalam ilmu biologi dan sosial. Jurnal Internasional Psikiatri dalam Kedokteran, 5 (4), 335-357. http://dx.doi.org/ 10.2190 / 91DKNKAD-1XP0-Y4RG

Maryani. (2013). Manfaat Terapi Tawa Untuk Kesehatan. http://www.tnol.co.id/bugar/21399ini-dia-8-manfaat-tertawa.html. Diakses : tanggal 3 November 2013.

Muhammad, A. (2011). Tertawalah Biar Sehat. Jakarta : Divia Press

Muwarti, I. (2013, November). Kriteria Diagnostik Gangguan Autistik. Lokakarya Penatalaksanaan Anak Autis, factor-faktor anak autisme. Yayasan Autisme Indonesia. Jakarta.
Nursalam. (2008). Konsep \& penerapan metodologi penelitian ilmu keperawatan: pedoman skripsi, tesis dan instrument penelitian keperawatan, Edisi: 1. Jakarta: Salemba Medika.

Notoatmodjo, S. (2010). Metode Penelitian Kesehatan. Jakarta: Rineka Cipta.

Perciso, Napolioni. (2013). Autisme : Pemahaman Baru untuk Hidup Bermakna Bagi Orang tua.

Pisula, E \& Kossakawska, Z. (2013). Sense of Coherence and Coping with Stress Among Mothers and Fathers og Children with Autisme. Journal Autisme Dev Disord, 40:1485-1494. DOI 10.1007/s10803-010-1001-3

Psychology Foundation of Australia. Depression 10. anxiety stress scales. [series online] 2010 [cited October 2015]. Available from: URL: http://www2.psy.unsw.edu.au/dass/I ndonesian/Damanik.htm

Riskesdas, (2015), Data Gender dan Anak. Daerah Istimewa Yogyakarta : 2015

Safary , Ryni. Retardasi Mental. Diakses pada1 Mei 2015darihttp://portalkalbe.com/

Sastry, Ida Erni.(2014). Hubungan antara Tingkat Stres dengan Pola Asuh Orang tua pada Anak Autisme di Kota Denpasar. Tesis. S2 Magister Keperawatan UGM. Yogyakarta : Universitas Gadjah Mada.

Siegel B. (2010) The Word of The Autistic Child. Oxford University Press New York.

Sun, X., Allison, C, (2010), Researchin Autism Spectrum Disorder 4. Hal: 
156-267. [Journal homepage: http//ees.elsevier.com/RASD/default. asp]

Sarwono. (2010). Metode Penelitian Kesehatan: Penuntut Praktis Bagi Permula. Jogyakarta: Mitra Cendikia.

Sarafino, (2011).Health Psychology stress, Biopsychological Interactions.Seventh edition. New York : John Wiley \& Sons Inc.

Setiadi, (2007).Konsep Dan Penelitian Riset Keperawatan, Yogyakarta: Graha Ilmu.

Suraiya, (2012) Strategi Koping dan Stres Pada Ibu Yang Memiliki Anak Yang Menderita Retardasi Mental. Jurnal Psikologi. Universitas Islam Negri Sultan Syarif Kasim: Riau.

Sukoco, Lumongga. (2014). Depressi dan persepsi stres. Penelitian dan Ulasan Pendidikan, 7 (5), 127-132. http://dx.doi.org/10.5897/

Terapi Tertawa. Lee berk (2012), Terapi Tertawa Diundu Dari Http: //www.holistie-online.com/hormontherapy/humor-therapyintroduction.htm.

WHO. (2016), Autisme Spectrum Disorders. [https://www.who.int/mediacenter/fa ctsheets/autismspectrumdisorders/en/
Yusuf A. Manajemen Stres. TOT Basic Study Skill tahun 2012. Afailable from:http://www.unhas.ac.id 